\title{
A Case of Venous Malformation in Temporomandibular Joint Causing Stenosis of External Auditory Canal
}

\author{
Sihong Choe ${ }^{1}$, Donghoo Lee ${ }^{1}$, Mi Seon Kang ${ }^{2}$, and Kyung Wook Heo ${ }^{1}$ iD \\ ${ }^{1}$ Departments of Otorhinolaryngology-Head and Neck Surgery, ${ }^{2}$ Pathology, College of Medicine, Inje University, Busan Paik Hospital, \\ Busan, Korea
}

\section{외이도 협착을 유발한 턱관절 정맥 기형 1 예}

최시홍 ${ }^{1} \cdot$ 이동후 $^{1} \cdot$ 강미선 $^{2} \cdot$ 허경욱 $^{1}$

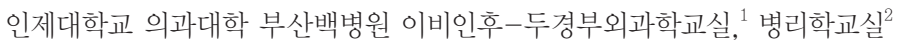

\author{
Received January 29, 2018 \\ Revised April 19, 2018 \\ Accepted May 16, 2018 \\ Address for correspondence \\ Kyung Wook Heo, MD \\ Department of Otorhinolaryngology- \\ Head and Neck Surgery, \\ College of Medicine, Inje University, \\ Busan Paik Hospital, \\ 75 Bokji-ro, Busanjin-gu, \\ Busan 47392, Korea \\ Tel $+82-51-890-6379$ \\ Fax $+82-51-892-3831$ \\ E-mail heokw96@daum.net
}

Both neoplasm and infections arising from the external auditory canal (EAC) can involve the temporomandibular joint (TMJ) but rarely the reverse. A benign TMJ mass that presents as an EAC mass is a rare otologic entity as only seven cases have been reported worldwide. The authors experienced a 72-year-old male patient presenting with EAC mass with fluctuation when opening the mouth, which turned out to be caused by venous malformation of the TMJ. Surgical excision of the mass via endaural approach was successful. We present this case with a review of the literature. Korean J Otorhinolaryngol-Head Neck Surg 2019;62(5):299-302

Key Words External auditory canal · Temporomandibular joint · Vascular malformation . Veins.

\section{서 론}

외이도와 턱관절은 밀접한 해부학적 관계를 가진다. 외이 도의 전벽은 하악골의 관절구(mandibular condyle)와 측두 골의 관절와(glenoid fossa)가 관절하는 부분과 닿아 있어, 외이도에서 발생한 신생물이나 염증이 턱관절을 침범할 수 있으나 턱관절에서 발생한 종물이 외이도를 침범하는 경우 는 매우 드물다. ${ }^{1)}$ 턱관절에서 발생한 종물이 외이도를 침범 한 경우는 전 세계적으로 약 7예가 보고된 바 있으며, 국내에 서는 보고된 적은 없다. ${ }^{1,2)}$ 특히 턱관절에서 발생한 정맥 기형 이 외이도를 침범한 경우는 전 세계적으로 1예만이 보고되어 매우 드물다. ${ }^{2)}$

저자들은 이충만감을 주소로 내원한 환자에서 턱관절에

This is an Open Access article distributed under the terms of the Creative Commons Attribution Non-Commercial License (https://creativecommons.org/licenses/by-nc/4.0) which permits unrestricted non-commercial use, distribution, and reproduction in any medium, provided the original work is properly cited.
서 발생한 정맥 기형이 외이도를 침범한 1 예를 이내 접근법 으로 제거하여 좋은 결과를 경험하였기에 문헌고찰과 함께 보고하고자 한다.

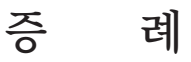

72세 남자 환자가 4일 전부터 발생한 좌측 이충만감을 주 소로 개인 의원에서 외이도 종물이 발견되어 3차 병원 이비 인후과로 의뢰되었다. 문진에서 좌측 이충만감 외에 턱관절 을 움직일 때 좌측 귀에서 소리가 나는 것을 호소하였다. 환 자는 5년 전 위암으로 위절제술을 시행 받은 것 이외에 두부 외상이나 수술, 턱관절, 귀 관련 질환 등의 과거력은 없었다. 이학적검사상 좌측 외이도 전벽에 약 $0.5 \mathrm{~cm}$ 직경의 백색 종 물이 관찰되고 고막은 종물로 인해 일부 가려져 있었으며, 종 물과 고막 사이에는 가피가 쌓여 있었다. 입을 다물고 있을 때 종물은 외이도로 돌출되고(Fig. 1A) 입을 벌릴 때는 종물 
의 일부가 턱관절 쪽으로 함몰되는 소견이었다(Fig. 1B). 우 측 외이도의 전벽에도 약 $0.3 \mathrm{~cm}$ 직경의 백색으로 보이는 부 분이 관찰되었는데, 입을 벌리더라도 백색 부분에는 변동이 없어서 정상적으로 존재할 수 있는 골성 외이도 전벽의 결손 으로 판단되었다(Fig. $1 \mathrm{C}$ ). 순음청력검사상 우측 $31 \mathrm{~dB}$ 및 좌측 $20 \mathrm{~dB}$ 의 기도역치(6분법) 였으며 양측 중저주파수에서 약 $10 \mathrm{~dB}$ 의 기도-골도 차이가 있었고, $4 \mathrm{kHz}$ 이상의 고음역 에서 경한 신경성 난청이 관찰되었으며, 고실도 검사는 양측 $\mathrm{A}$ 형이었다. 그 외 이비인후과적 진찰상 특이 소견은 없었다. 조영증강 컴퓨터단층촬영에서 외이도 전벽에 약 $0.7 \mathrm{~cm}$ 직경 의 조영증강되지 않는 연조직 병변과 외이도 전벽의 골 결손 이 관찰되었다(Fig. 2A and B). 자기공명영상검사상 T2 강조 영상에서는 높은 신호를 보이는 턱관절 종물이 외이도로 확 장된 소견이었다(Fig. $2 \mathrm{C}$ ). 외래에서 절개 생검을 시행하였으 나 표면의 정상 피부만 채취되어 조직진단을 얻지 못했으며,
환자의 위암 과거력 때문에 전이 병변의 여부를 조직학적으 로 진단하기 위해 수술적 제거를 결정했다.

수술 시 턱관절의 손상 가능성에 대해 동의를 얻은 후 기관 삽관을 통한 전신마취를 시행했다. 이내 절개를 시행한 후 종물의 외측 $0.2 \mathrm{~cm}$ 부위의 외이도 전벽에 상하 방향의 절개 를 시행하고 골성 외이도(bony external auditory canal wall) 로부터 외이도 피부를 거상한 다음, 종물 외측의 골성 외이도 를 $2 \mathrm{~mm}$ cutting burr로 일부 제거하여 종물을 노출 시켰다 (Fig. 3A). 해당 종물은 관절낭(joint capsule)과 골성 외이도 사이에 존재하였고, 수술 중 관절낭이 부분적으로 노출되었 으나 정상 소견이었다. 노출된 종물을 미세 수술기구로 박리 하여 턱관절 내부의 정상 연조직과 분리했으며 박리 과정에 서 소량의 출혈이 있어 양극 소작기로 지혈을 시행했다. 제거 된 종물은 $0.8 \times 0.5 \times 0.3 \mathrm{~cm}$ 의 크기로 붉은빛을 띠었다(Fig. 3B). 종물을 제거한 후 수술 전 정상이었던 고막의 전방부에
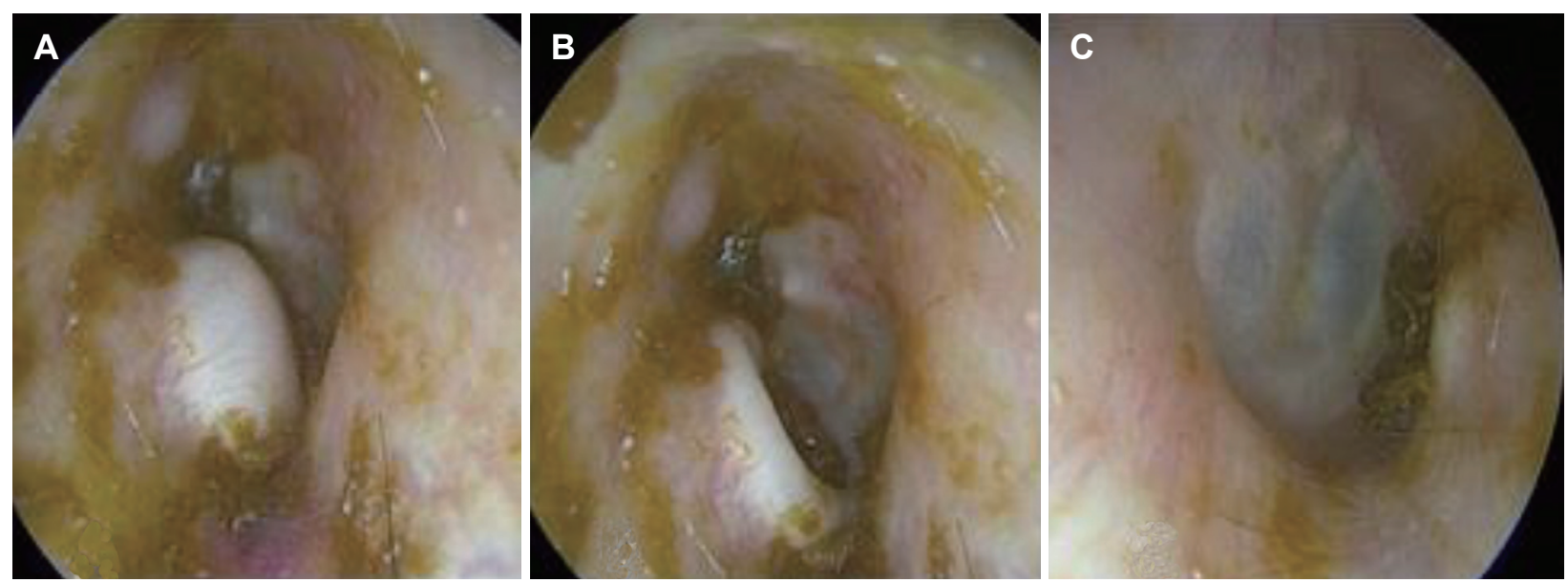

Fig. 1. Preoperative otoscopic finding of both EACs. Left ear showed a protruding whitish mass at the anterior EAC wall while closing mouth (A). The mass seems to collapse partially into the temporomandibular joint while opening mouth (B). Also, the anterior EAC wall of right ear showed whitish area without fluctuation during mouth opening (C). Both tympanic membranes were intact. EAC: external auditory canal.

Fig. 2. Preoperative computed tomogram (axial A and coronal B) and MRI $(C)$ of left ear. There was a $0.7 \mathrm{~cm}$ sized protruding mass (arrows) to EAC from TMJ and defect in anterior bony wall of EAC without enhancement by contrast. Coronal T2 weighted MRI demonstrates a lesion with high signal in the TMJ with extension posteriorly to EAC (arrow). EAC: external auditory canal, TMJ: temporomandibular joint, MRI: magnetic resonance imaging.
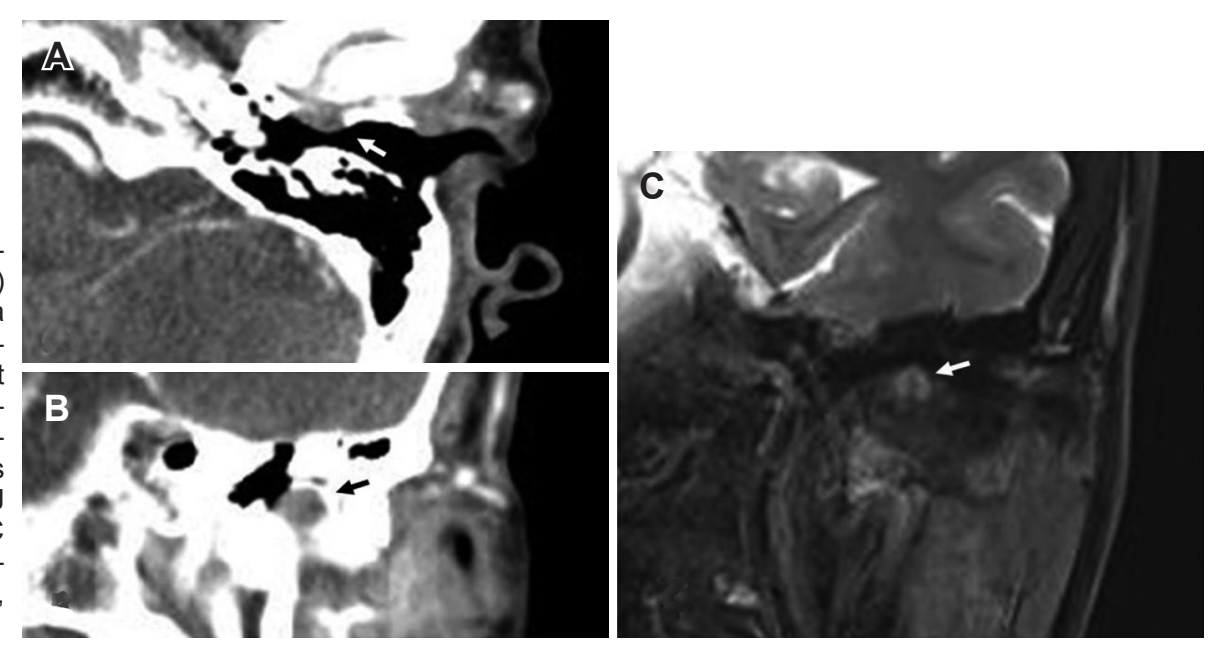
천공이 발견되어 이주 연골과 연골막으로 1형 고실 성형술을 시행했다. 종물 제거 후 골성 외이도 결손부의 크기는 약 $0.7 \times$ $0.8 \mathrm{~cm}$ 이었으나 모든 방향에서 정상 골성 외이도가 관찰되었 으므로, 수술 후에도 턱관절 이탈증(herniation)은 발생하지 않을 것으로 예상되어 골성 외이도 전벽의 결손은 재건하지 않았다. 고실 외이도 피판과 외이도 피부를 모두 재위치 시킨 후 외이도를 나일론 거즈로 충전하고 수술을 마쳤다. 종물에 대한 병리조직검사상 다양한 크기와 모양으로 늘어난 혈관 들이 다수 관찰되었으며 혈관들은 비교적 두꺼운 벽을 가지 고 있었고 일부는 서로 문합하는 양상이었다. 내강은 납작한 한 층의 혈관내피세포로 덮여 있었으며 적혈구가 관찰되어 정맥 기형으로 진단되었다(Fig. $3 \mathrm{C}$ ). 환자는 특이 합병증 없 이 수술 후 1 일째에 퇴원하였고, 수술 후 2 개월 뒤 환자는 이 충만감이 사라졌으며, 턱 움직일 때 좌측 귀에서 더 이상 소 리도 들리지 않는다고 하였다. 병원 방문 시 진찰상 턱관절 이탈증의 소견 없이 정상적인 외이도와 고막 소견을 보이고 있었으며 저작시에도 일관된 외이도의 모습을 보였다(Fig. 3D). 순음청력검사상 기도 역치는 우측 $30 \mathrm{~dB}$ 및 좌측 26 $\mathrm{dB}$ 이었고 양측에 기도-골도 차이는 약간 증가되어 있었다. 현재 환자는 수술을 시행 받은 지 1년째로 외이도 및 고막에 재발된 소견 없이 정기적인 외래 관찰 중에 있다.

\section{고 찰}

턱관절은 관절낭(capsule), 관절원반(articular disc), 활액막 (synovial lining), 인대로 구성되어 있다. ${ }^{3)}$ 턱관절에서 종양의 발생은 매우 드물며 활액막연골종(synovial chondromatosis), 골연골종(osteochondroma), 골종 등의 양성 종양이 보고된 바 있고 ${ }^{4,5)}$ 드물게는 윤활막육종(synoviosarcoma), 골수세포 종(myelocytoma) 등의 악성 종양도 발생할 수 있으며,") 드물 게 타 장기의 악성 종양이 턱관절로 전이되기도 하기 때문에 조직 검사를 통한 감별이 필요하다. ${ }^{47,8)}$ 본 증례 환자의 경우 위암의 과거력이 있었으므로 조직 검사를 통한 전이 여부의 확진이 필요했으나, 국소마취하에 외래에서 시행한 조직 검 사상에는 피하 조직을 채취할 수가 없어서 수술을 통한 종 물의 제거와 병리 검사를 시행했다.

턱관절 종물에 의한 증상은 종물의 크기와 위치에 따라 달라질 수 있는데 관절 부위나 귀의 통증을 호소하는 경우가 가장 흔하며 관절 부위 마찰음, 부종, 관절의 움직임 장애 등 이 동반될 수 있다." 만약 종물의 크기가 클 경우 뇌신경을 침범하여 안면신경 마비나 이개의 감각신경 마비로 감각저하 가 나타나기도 하고, ${ }^{9,10)}$ 개구장애나 턱의 비대칭을 유발할 수 있다. ${ }^{11)}$ 이 경우 조기 진단과 적절한 치료로 환자 삶의 질을 유 지하도록 해야 하는데 본 증례의 경우 종물의 크기가 작아서 이충만감과 저작 시 이명만을 호소했던 것으로 판단된다.

턱관절에서 발생한 종물이 외이도를 침범한 사례는 매우 드문데 Williams 등에 에 의하면 청력감소, 이통, 턱관절 통증, 부종, 두통, 마찰음 등 다양한 증상을 호소할 수 있으며, 종 물의 크기가 커질수록 종물의 내측에 존재하는 정상 외이도 피부에서 발생하는 각질로 인해 외이도 진주종을 일으킬 수
Fig. 3. Intraoperative and postoperative findings. Operative microscopic finding after EAC skin elevation and the exposure of the mass (asterisk) (A). The excised mass was reddish and $0.8 \times 0.5 \times 0.3 \mathrm{~cm}$ sized (B). Microscopic examination revealed congested and irregularly dilated vessels with flat endothelium (hematoxylin and eosin stain, $\times 200$ ) (C). Postoperative otoendoscopic finding of ear showed intact left tympanic membrane and EAC without movement during opening mouth (D). EAC: external auditory canal.
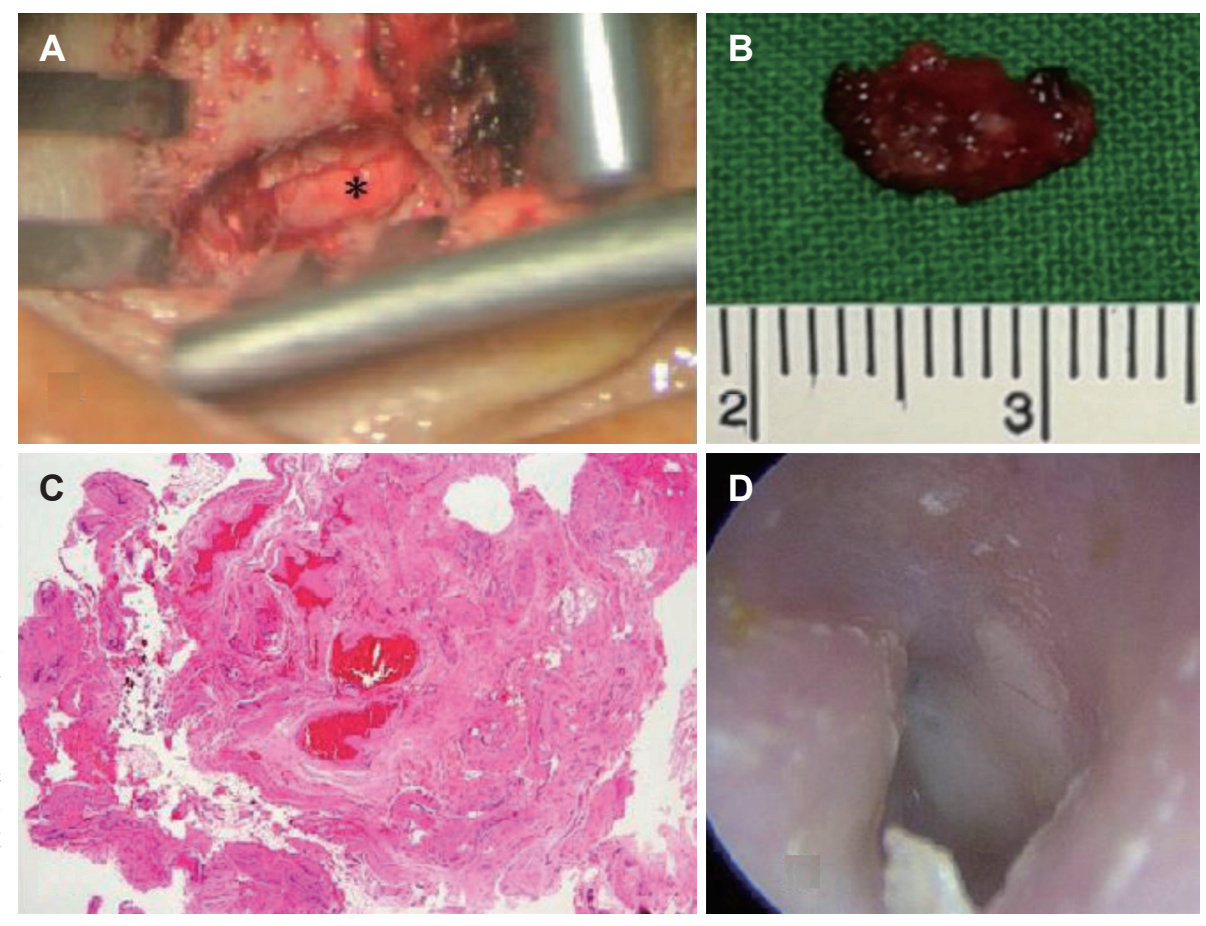
있다. 턱관절에서 발생한 종물의 외이도 침범은 외이도 기원 의 편평상피암 또는 선종 등에 의한 턱관절 침범과 감별이 필요하며, 가급적 빠른 시간 내에 조직학적 확인이 필요하 다. ${ }^{1)}$ 외이도 종물의 조직 검사를 시행하기 전에 컴퓨터단층 촬영이나 자기공명영상을 이용한 영상검사로 병변의 대략적 인 성상과 혈관과의 관계에 대한 정보를 얻는 것이 중요하며, 추후 수술적 접근 방법을 결정하는데도 도움을 얻을 수 있 다.,9,11) 턱관절에서 발생한 종물이 외이도를 침범의 경우 턱 관절강을 통한 접근, 후이개 접근, 또는 이내 접근을 통한 종 물 절제가 가능하며 조직 소견이 확진된 후 필요에 따라 방 사선 치료를 추가로 시행하게 된다. ${ }^{1)}$

턱관절에서 발생한 종물이 외이도를 침범했던 기존의 보 고들에서는 융모결절 윤활막염(villonodular synovitis), 결절 근막염(nodular fasciitis), 연성 섬유종(fibroepithelial polyp), superficial angiomyxoma, 거대세포종(giant cell tumor) 등 이었으며, 본 증례는 정맥 기형으로 최종 진단되었다. ${ }^{1}$

정맥 기형(venous malformation)은 선천적인 혈관 발달의 이 상으로 알려져 있고 혈관계 기형 중 가장 흔하며, 동맥과의 연 결이 없는 저속 혈류를 보인다. ${ }^{12,13)}$ 발병률은 5 천 1 만 명당 1 명 정도이고 정맥이 분포하는 몸의 어디든지 발생 가능하여 소아기에 발견되는 것이 보통이지만, 위치나 크기에 따라 성 인에서 발견되는 경우도 흔히 보고된다. ${ }^{12)}$ 병변은 몸이 성장 하는 비율에 따라 자라고 저절로 퇴행하는 경우는 매우 드문 것으로 알려져 있으며, 발생 부위 중 두경부 영역에 발생하는 경우가 약 $40 \%$ 로 가장 흔하다. ${ }^{13)}$

조직학적으로 혈관종은 증식된 내피세포와 비반세포를 보 이는데 정맥 기형은 성숙한 내피세포와 정상 비반세포 수를 가지는 것이 특징이고, 혈관벽에 평활근 없이 단층의 성숙한 내피세포에 의해 둘러싸인 얇은 벽의 혈관으로 구성된다. ${ }^{12)}$ 정맥 기형의 증상은 종괴 효과로 인한 것이 대부분으로 국소 적인 압박감, 통증, 출혈 등의 증상이 있을 수 있다. ${ }^{2)}$ 종물은 대부분 부드럽게 촉지되고, 압박 시 쉽게 압축이 되며 압박 을 해제하면 부풀어 오르고, 발살바법을 시행할 때 그 크기 가 증가하는 것을 관찰할 수 있다.,12)

진단은 이학적 소견, 전산화단층촬영, 자기공명영상, 그리 고 정맥 조영술 등으로 내리게 된다. ${ }^{12,13)}$ 치료는 크기가 작고 증상이 없는 병변의 경우 보존적인 치료로 경과 관찰만 시행 하기도 하지만 증상을 유발하는 경우 경화제의 병변 내 주입 을 통한 경화 요법을 사용하는 경우가 많으나, 국소적이고 한 정된 크기의 병변인 경우 외과적 절제를 통해 제거하기도 한 다. 그 밖에도 방사선 요법이나 스테로이드, 레이저, 냉동요법 등이 시도되고 있다. ${ }^{12,13)}$ 본 증례의 경우 병변의 조직학적 확 진이 필수적이었으므로 수술적 절제를 통한 치료를 시행했
으며, 골성 외이도의 넓이에 비해 병변이 비교적 작아서 이내 접근법으로 완전 절제할 수 있었다. 또한, 병변이 수술 전에 고막과 접촉되어 있는 상태였으므로 수술 시 고막 천공이 병 발했던 것으로 판단된다. 저자들은 고막 재건 시 수술 후 외이 도 전벽의 결손을 통해 하악골의 관절구(mandibular condyle) 가 외이도로 돌출되어 고막과 접촉되어 천공이 다시 발생할 가능성을 염두에 두어, 연조직보다는 강도가 있는 연골을 사 용해 고막의 재건을 시행했다.

이상과 같이 저자들은 위암의 과거력이 있는 성인 남자 환 자에서 발견된 턱관절 정맥 기형을 이내접근법으로 성공적 으로 제거했기에 이를 보고하는 바이다.

\section{ORCID}

Kyung Wook Heo https://orcid.org/0000-0002-4729-0135

\section{REFERENCES}

1) Williams RA, Jackler RK, Corrales CE. Benign temporomandibular joint lesions presenting as masses in the external auditory canal. Otol Neurotol 2017;38(4):563-71.

2) Zhou Q, Yang C, Chen MJ, Qiu YT, Qiu WL, Zheng JW. Primary intraand juxta-articular vascular malformations of the temporomandibular joint: a clinical analysis of 8 consecutive patients. Int J Clin Exp Med 2015;8(2):2247-53.

3) Sun WH, Wang PC. Temporomandibular joint capsule rupture presenting as expandable ear canal mass. J Formos Med Assoc 2018; 117(1):80-1.

4) Poveda-Roda R, Bagán JV, Sanchis JM, Margaix M. Pseudotumors and tumors of the temporomandibular joint. Med Oral Patol Oral Cir Bucal 2013;18(3):392-402.

5) Warner BF, Luna MA, Robert Newland T. Temporomandibular joint neoplasms and pseudotumors. Adv Anat Pathol 2000;7(6):365-81.

6) Wei WB, Chen MJ, Yang C, Qiu Y, Zhou Q. Tumors and pseudotumors at the temporomandibular joint region in pediatric patients. Int J Clin Exp Med 2015;8(11):21813-7.

7) Pretzl C, Lübbers HT, Grätz KW, Kruse AL. [Metastases in the temporomandibular joint: a review from 1954 to 2013. rare causes for temporomandibular disorders]. Swiss Dent J 2014;124(10):1067-83.

8) Guarda-Nardini L, Stellini E, Di Fiore A, Manfredini D. A rare case of misdiagnosed silent lung cancer with solitary metastasis to the temporomandibular joint condyle. J Oral Facial Pain Headache 2017; 31(2):180-5.

9) Savolainen JJ, Kellokoski JK. Ganglion cyst of the temporomandibular joint. Int J Oral Maxillofac Surg 2013;42(6):776-9.

10) Mumert ML, Altay T, Shelton C, Harnsberger HR, Couldwell WT. Ganglion cyst of the temporomandibular joint with intracranial extension in a patient presenting with seventh cranial nerve palsy. $\mathrm{J}$ Neurosurg 2012;116(2):310-2.

11) Misra N, Srivastava S, Bodade PR, Rastogi V. Osteoma of temporomandibular joint: a rarity. BMJ Case Rep 2013;2013: bcr2013200268.

12) Jin JW, Sung MW, Lim YS, Park BJ, Roh JL, Seong WJ et al. [Sclerotherapy for craniofacial venous malformation]. Korean J Otolaryngol 2002;45:387-92.

13) Zheng JW, Mai HM, Zhang L, Wang YA, Fan XD, Su LX, et al. Guidelines for the treatment of head and neck venous malformations. Int J Clin Exp Med 2013;6(5):377-89. 